\title{
Reaction norm variation between and within populations of two rare plant species, Vicia pisiformis and $V$. dumetorum (Fabaceae)
}

\author{
SANNA BLACK-SAMUELSSON* \& STEFAN ANDERSSONं \\ *Department of Forest Genetics, Swedish University of Agricultural Sciences, PO Box 7027, S-750 07 Uppsala and \\ + Department of Systematic Botany, University of Lund, Östra Vallgatan 18-20, S-223 61 Lund, Sweden
}

\begin{abstract}
A split-family design with progenies grown across a steep temperature gradient was used to examine the patterns of reaction norm variation in two locally rare, thermophilous plant species, Vicia pisiformis and V. dumetorum. We predicted (i) a negative association between the amount of genetic variation and the magnitude of response across temperatures; (ii) broader ecological tolerance and higher levels of genetic variation for reaction norm parameters in the broadly adapted $V$. dumetorum than in the ecologically restricted $V$. pisiformis; and (iii) higher performance across environments for central populations than for geographically marginal populations. Patterns of variation in 10 vegetative characters, including measures of overall plant size, provided no evidence of a trade-off between plasticity and genetic variation. Our data indicate greater performance across temperatures and more divergent genotypes in $V$. dumetorum than in $V$. pisiformis. Central populations of $V$. pisiformis performed better than conspecific populations from the marginal (northern) regions.
\end{abstract}

Keywords: genetic variation, genotype $\times$ environment interaction, phenotypic plasticity, rarity, Vicia dumetorum, Vicia pisiformis.

\section{Introduction}

Phenotypic plasticity, or the ability of an organism to modify its phenotype in response to changes in the environment, represents an important aspect of the reaction norm. It has been suggested that reaction norms can be changed by selection (Bradshaw, 1965; Schlichting \& Levin, 1984; Via \& Lande, 1985; Sultan, 1987) and that phenotypic plasticity and genetic variation represent alternative modes of adaptation in plants and other organisms in heterogeneous environments (Marshall \& Jain, 1968). According to the latter idea, one would expect genetically variable species or populations to be less plastic than those with low levels of heritable variation. Yet despite numerous attempts to test this hypothesis, there is little empirical evidence of an inverse relationship between plasticity and genetic variation (Marshall \& Jain, 1968; Scheiner \& Goodnight, 1984; Schlichting \& Levin, 1984; Taylor \& Aarssen, 1988; MacDonald \& Chinnappa, 1989; but see Cook \& Johnson, 1968; Silander, 1985).

\footnotetext{
*Correspondence. E-mail: sanna.black@sgen.slu.se.
}

A related idea, termed the 'ecology hypothesis' by Schlichting \& Levin (1984), predicts that the pattern of selection on plasticity differs from one habitat to another, leading to habitat-correlated variation in the reaction norm. Accordingly, one would expect greater diversity in reaction norm parameters in widespread and/or broadly adapted species than in rare species with narrow ecological amplitudes. However, although isozyme diversity tends to increase with the geographical range (Loveless \& Hamrick, 1984), there have been few attempts to examine whether rarity is associated with low variation of traits directly related to fitness (Widén \& Andersson, 1993; Ouborg \& Van Treuren, 1995), including phenotypic plasticity (Andersson \& Widén, 1993). Genetic differences in plasticity can be visualized as reaction norm diagrams and quantified as genotype-environment interactions (analysis of variance) or as the genetic correlation between the same character measured in two distinct environments (Schlichting \& Levin, 1984; Via \& Lande, 1985; Via, 1987).

Rabinowitz (1981) classified rare plant species into seven categories according to local population 
size, geographical range and habitat specificity. For example, Vicia pisiformis and $V$. dumetorum occur in large parts of Europe but are locally rare in the northern (marginal) areas, where climatic factors have restricted their expansion. Both species require high summer temperatures (Ellenberg et al., 1991), but $V$. dumetorum occurs in a wider range of habitats than $V$ p pisiformis (see below) and may therefore be considered as a commoner species (Rabinowitz, 1981). However, only genetic data can reveal whether these species owe their rarity to a lack of quantitative genetic variation, narrow ecological tolerance or historical factors (Kruckeberg \& Rabinowitz, 1985).

Previous work on $V$. pisiformis (Black et al., 1995) has revealed genetic variation for biomass and fecundity, and differences between populations in their phenotypic response to different temperatures, contrasting with the low genetic variation revealed with random amplified polymorphic DNA (RAPD) and restriction fragment length polymorphism (RFLP) (rDNA) (Gustafsson \& Gustafsson, 1994). In the study presented here, we quantified genetic variation and phenotypic plasticity in a wide range of vegetative traits in $V$. pisiformis and $V$. dumetorum over a broader range of temperature conditions. Our aims were to investigate the relationship between amounts of genetic variation and phenotypic plasticity, to test the supposition that $V$. dumetorum is more tolerant to changes in temperature or that this species shows higher levels of heritable or plastic variation than $V$. pisiformis, and to determine whether central and marginal populations differ in their response to temperature.

\section{Materials and methods}

\section{Species description}

Vicia pisiformis and $V$. dumetorum (Fabaceae) are diploid, herbaceous plants capable of limited vegetative reproduction. Both species are self-fertile (unpublished) and pollinated by bumble bees, honey bees and small solitary bees (Hanelt \& Mettin, 1989). Vicia pisiformis and $V$. dumetorum occur in large parts of Europe with a centre of distribution in Germany and the Czech Republic. Vicia pisiformis has about 30 localities in Sweden and Norway, and $V$. dumetorum is known from about 25 localities in Sweden. The northern (marginal) sites are geographically isolated with fewer than 300 ( $V$. pisiformis) or 2000 ( $V$. dumetorum) shoots per locality. Most populations have been small and isolated over the past 200 years. Vicia pisiformis and $V$. dumetorum are classified as 'vulnerable' and 'care-demanding', respectively, on the Swedish list of threatened plant species (Aronsson et al., 1995).

Vicia pisiformis and $V$. dumetorum are thermophilous (Ellenberg et al., 1991), but differ in their breadth of adaptation, at least in the northern regions. Vicia dumetorum occurs in a variety of natural and anthropogenic habitats, e.g. conifer and deciduous forests, edge-zones between forest and open land, gardens, road verges and ruderal sites (Gustafsson, 1992), whereas V. pisiformis is restricted to natural sites exposed to sunlight, e.g. south-facing slopes in deciduous forests (Gustafsson, 1991). The latter species has disappeared from many localities in Sweden as a result of increased competition from surrounding vegetation attributable to spontaneous closing of forests and plantation with conifers (Gustafsson, 1991).

\section{Experimental procedures}

Seeds were collected from five to nine (mostly seven) maternal plants in each of 13 populations representing marginal (Sweden and Norway) and central (Germany and Czech Republic) localities of both species (see Table 1 for geographical locations). To minimize the risk of repeated sampling within clones, seeds were collected from plants separated by at least $3 \mathrm{~m}$. The seeds were pooled across pods and kept separate by maternal parent (hereafter 'family'). Average seed weight for each family was determined by weighing a bulked seed sample of

Table 1 Geographical location of populations of Vicia pisiformis and $V$.dumetorum used in the present study

\begin{tabular}{llll}
\hline Population & Location & $\begin{array}{c}\text { Latitude } \\
\text { (north) }\end{array}$ & $\begin{array}{c}\text { Longitude } \\
\text { (east) }\end{array}$ \\
\hline V. pisiformis & & & \\
Borgehall & Sweden & $58^{\circ} 30^{\prime}$ & $13^{\circ} 40^{\prime}$ \\
Rudu & Sweden & $57^{\circ} 50^{\prime}$ & $14^{\circ} 18^{\prime}$ \\
Björkåsholm & Norway & $59^{\circ} 47^{\prime}$ & $10^{\circ} 30^{\prime}$ \\
Sjöstrand & Norway & $59^{\circ} 47^{\prime}$ & $10^{\circ} 29^{\prime}$ \\
Chlum & Czech Republic & $50^{\circ} 23^{\prime}$ & $14^{\circ} 55^{\prime}$ \\
Unêticky' & Czech Republic & $50^{\circ} 08^{\prime}$ & $14^{\circ} 19^{\prime}$ \\
V. dumetorum & & & \\
Tullinge & Sweden & $59^{\circ} 13^{\prime}$ & $17^{\circ} 52^{\prime}$ \\
Krokek & Sweden & $58^{\circ} 39^{\prime}$ & $16^{\circ} 26^{\prime}$ \\
Kristinelund & Sweden & $55^{\circ} 54^{\prime}$ & $14^{\circ} 01^{\prime}$ \\
Ho. Junkershausen Germany & $50^{\circ} 21^{\prime}$ & $10^{\circ} 21^{\prime}$ \\
Hart & Germany & $49^{\circ} 50^{\prime}$ & $10^{\circ} 04^{\prime}$ \\
Chlum & Czech Republic & $50^{\circ} 23^{\prime}$ & $14^{\circ} 55^{\prime}$ \\
Prühonice & Czech Republic & $50^{\circ} 00^{\prime}$ & $14^{\circ} 34^{\prime}$ \\
\hline
\end{tabular}


11-20 seeds per family, with the exception of the Unêticky' population, in which each bulk sample consisted of 18-40 seeds.

After scarification and imbibation in water, the seeds were quickly dipped in Vitaflow 6 per cent to eliminate fungus infections. The seeds were sown in pots with a mixture of perlite, vermiculite, sand and gravel, and the pots were placed in a phytotron $\left(20^{\circ} \mathrm{C}, 24 \mathrm{~h}\right.$ light $)$. After the development of the first leaf, seedlings were planted in mineral wool 'Grodan' and incubated at $18^{\circ} \mathrm{C}$ for $16 \mathrm{~h}$ light and at $12^{\circ} \mathrm{C}$ for $8 \mathrm{~h}$ darkness for $2-3$ weeks. The initial length of each plant (LENG) was measured, and pots with equal-sized plants were placed in the same block, in order to obtain uniform blocks, before transfer to growth chambers representing the following temperature regimes: $12^{\circ} \mathrm{C} / 7^{\circ} \mathrm{C}, 17^{\circ} \mathrm{C} / 12^{\circ} \mathrm{C}$, $22^{\circ} \mathrm{C} / 17^{\circ} \mathrm{C}$ and $27^{\circ} \mathrm{C} / 22^{\circ} \mathrm{C}$ (day/night temperature). This gradient spans the full range between the high summer temperatures in the central parts of the range to the lower summer temperatures prevailing in the northern parts. Each of the 13 populations was represented by one plant in each of 14 blocks within each temperature treatment, resulting in a total of 728 plants (13 populations $\times$ four treatments $\times 14$ plants). Each family was represented by one to three (mostly two) offspring per temperature regime. The plants were grown in transparent plastic tubes to simplify harvest and to minimize competition. The plants were watered with a nutrient solution according to their size, i.e. plants in warmer treatments were given nutrient more frequently than plants in cooler treatments, a procedure that prevented stress symptoms seen in previous experiments (unpublished). The relative air humidity was 75 per cent at all temperature regimes.
All plants were harvested after approximately 6 weeks when the plants in the $27^{\circ} \mathrm{C} / 22^{\circ} \mathrm{C}$ treatment had reached the height of the plastic tubes $(170 \mathrm{~cm})$. Each plant was scored for the variables in Table 2. Traits reflecting growth rate and overall plant performance (SHOOT, MLENG, DWTOT) are directly related to flower production and may therefore be under positive selection irrespective of growth conditions, whereas the other characters (ratios and leaf variables) may be selectively neutral or subject to more complex patterns of selection. Some of the variables are likely to be redundant, but each is expected to provide at least some information not revealed by the other traits. The dry weight of root and above ground material was recorded after drying for $40 \mathrm{~h}$ at $70^{\circ} \mathrm{C}$. Analysis of residuals showed that all traits were approximately normally distributed, except for DWSHO, which was logtransformed.

\section{Statistical analyses}

Nested, factorial analysis of variance was conducted for each variable using type III sum of squares (PROC GLM; SAS, 1989) with treatment and species considered as fixed effects and population (nested within species) and family (nested within population) as random effects. Preliminary analyses revealed nonsignificant effects of block and initial length (covariate), so these factors were excluded from the final analyses. Analyses of the full data set were based on the following statistical model (referred to as 'model 1 '): trait $=$ treatment + species + population + treatment $\times$ species + treatment $\times$ population + error, whereas separate analyses for each species included 'family' and 'family $\times$ treat-

Table 2 Character abbreviation and description of vegetative traits measured in Vicia dumetorum and $V$ pisiformis

\begin{tabular}{ll}
\hline Character & Description (unit, type of transformation) \\
\hline SHOOT & $\begin{array}{l}\text { Number of basal shoots } \geq 10 \mathrm{~cm} \\
\text { MLENG }\end{array}$ \\
LWARth of main shoot $(\mathrm{cm})$ \\
DWTOT & Dry weight ratio above ground/root material \\
DWSHO & Dry weight/shoot $(\mathrm{g}$, log-transformed) \\
DWNODE & Dry weight/node $(\mathrm{g})$ \\
NODESHO & Number of nodes $/$ shoot \\
BRANODE & Number of branches $\geq 10 \mathrm{~cm} /$ node \\
LEAFL & Length of leaflet closest to stem at sixth node $(\mathrm{mm})$ \\
LEAFS & Ratio leaf length/leaf width at widest point on \\
& leaflet closest to stem at sixth node \\
\hline
\end{tabular}


ment' as additional factors ('model 2'). The approximate error term for each $F$-test was synthesized with the Satterthwaite approximation using the TEST option in the RANDOM statement of PROC GLM (SAS, 1989). The fraction of variance accounted for by each of the random factors was calculated as the ratio of the variance component to the sum of all components. Estimates of the variance components were obtained using the REML option in PROC VARCOMP (SAS, 1989), and the standard errors of the relative components were found using the Delta technique (Bulmer, 1980).

To quantify the elevation of the reaction norm for each population, we averaged the treatment means for each character, whereas the amount of response (i.e. the slope of the reaction norm) was quantified as the coefficient of variation of treatment means $(\mathrm{CV}=$ standard deviation/mean $)$. We also calculated the product-moment correlation coefficient $(r)$ between the mean of each population in the most extreme environments $\left(12^{\circ} \mathrm{C} / 7^{\circ} \mathrm{C}, 27^{\circ} \mathrm{C} / 22^{\circ} \mathrm{C}\right)$ to test whether increased adaptation to low temperatures has been achieved at the expense of decreased adaptation to high temperatures, i.e. whether genetically based trade-offs within the reaction norm have prevented the species from exploiting a wider range of temperature environments. Such trade-offs are indicated if $r$ is negative for characters directly related to fitness (Via, 1987).

\section{Results}

Phenotypic plasticity and genetic differences in the overall mean

The main effect of treatment was significant in all cases, with the exception of SHOOT ( $V$. pisiformis) and LEAFS (both species; Table 3). Judging by the reaction norms (Fig. 1), most characters showed a positive response to increasing temperature. The average amount of response (CV) was highest for DWAR and BRANODE and lowest for LEAFL and LEAFS, but differed little between species (Table 4).

Vicia dumetorum was characterized by higher mean values for SHOOT, MLENG, DWAR, BRANODE and LEAFS, whereas $V$. pisiformis had higher means for DWNODE and LEAFL (Fig. 1, Tables 4 and 5). Separate analyses for each species

Table 3 Results of nested, factorial analysis of variance of 10 vegetative traits in Vicia pisiformis and V. dumetorum

\begin{tabular}{lccccc}
\hline Character & Treatment & Population & $\begin{array}{c}\text { Family } \\
\text { (population) }\end{array}$ & $\begin{array}{c}\text { Treatment } \times \text { population } \\
(15)\end{array}$ & $\begin{array}{c}\text { Treatment } \times \text { family } \\
\text { (population) }\end{array}$ \\
\hline V. pisiformis & $(3)$ & $(5)$ & $(36)$ & $1.789^{*}$ & $(99)$ \\
SHOOT & 0.764 & $6.376^{* *}$ & 0.915 & 0.620 & 0.996 \\
MLENG & $526.676^{* * *}$ & $6.076^{*}$ & 0.993 & $5.967^{* * *}$ & 0.970 \\
DWAR & $74.331^{* * *}$ & $3.977^{*}$ & 1.111 & $1.976^{*}$ & 0.922 \\
DWTOT & $62.413^{* * *}$ & $4.747^{* *}$ & $1.710^{*}$ & 0.567 & 0.988 \\
DWSHO & $235.770^{* * *}$ & 2.084 & 1.124 & 0.499 & 1.099 \\
DWNODE & $127.383^{* * *}$ & 1.745 & 1.026 & 1.420 & 1.110 \\
NODESHO & $93.749^{* * *}$ & 1.192 & 1.000 & 0.875 & 0.976 \\
BRANODE & $5.640^{* *}$ & 2.263 & 0.826 & 1.648 & 1.285 \\
LEAFL & $5.851^{* *}$ & $4.597^{*}$ & 1.056 & $2.028^{*}$ & $(124)$ \\
LEAFS & 1.008 & 2.099 & 1.157 & $(18)$ & 1.135 \\
V. dumetorum & $(3)$ & $(6)$ & $(43)$ & $2.224^{* *}$ & 1.017 \\
SHOOT & $23.110^{* * *}$ & $2.436^{*}$ & $2.101^{* * *}$ & 1.027 & 1.154 \\
MLENG & $551.289^{* * *}$ & 2.123 & 1.273 & $5.232^{* * *}$ & $1.344^{*}$ \\
DWAR & $79.211^{* * *}$ & 2.553 & $1.579^{*}$ & $2.701^{* * *}$ & $1.404^{*}$ \\
DWTOT & $62.819^{* * *}$ & 1.613 & $2.039^{* *}$ & $3.396^{* * *}$ & 0.949 \\
DWSHO & $76.642^{* * *}$ & 1.779 & 1.037 & $3.288^{* * *}$ & $1.530^{* *}$ \\
DWNODE & $41.184^{* * *}$ & $2.987^{*}$ & $1.550^{*}$ & $6.257^{* * *}$ & 0.898 \\
NODESHO & $28.055^{* * *}$ & 1.511 & 1.061 & $4.983^{* * *}$ & $1.486^{* *}$ \\
BRANODE & $29.368^{* * *}$ & 2.316 & $1.735^{* *}$ & 1.317 & 1.026 \\
LEAFL & $16.384^{* * *}$ & $6.141^{* *}$ & 1.047 & 0.847 & \\
LEAFS & 0.775 & $4.339^{* *}$ & 1.391 & & \\
\hline
\end{tabular}

Values are $F$-ratios (degrees of freedom in brackets).

${ }^{*} P \leq 0.05 ;{ }^{* *} P \leq 0.01 ;{ }^{* *} P \leq 0.001$.

(c) The Genetical Society of Great Britain, Heredity, 79, 268-276. 
revealed significant between-population variation for half of the characters in both species (Table 3), and the variance attributed to population accounted for $0-19$ per cent of the variation in $V$ pisiformis and for 3-14 per cent of the variation in $V$. dumetorum (Table 6). Although central populations of $V$. pisiformis performed better across environments (larger means for SHOOT, MLENG and DWTOT) than populations in marginal areas, there was no clear regional pattern in $V$. dumetorum (Fig. 1).

Families within populations of $V$ pisiformis differed significantly only for DWTOT, whereas populations of $V$. dumetorum showed a significant between-family component for SHOOT, DWAR,
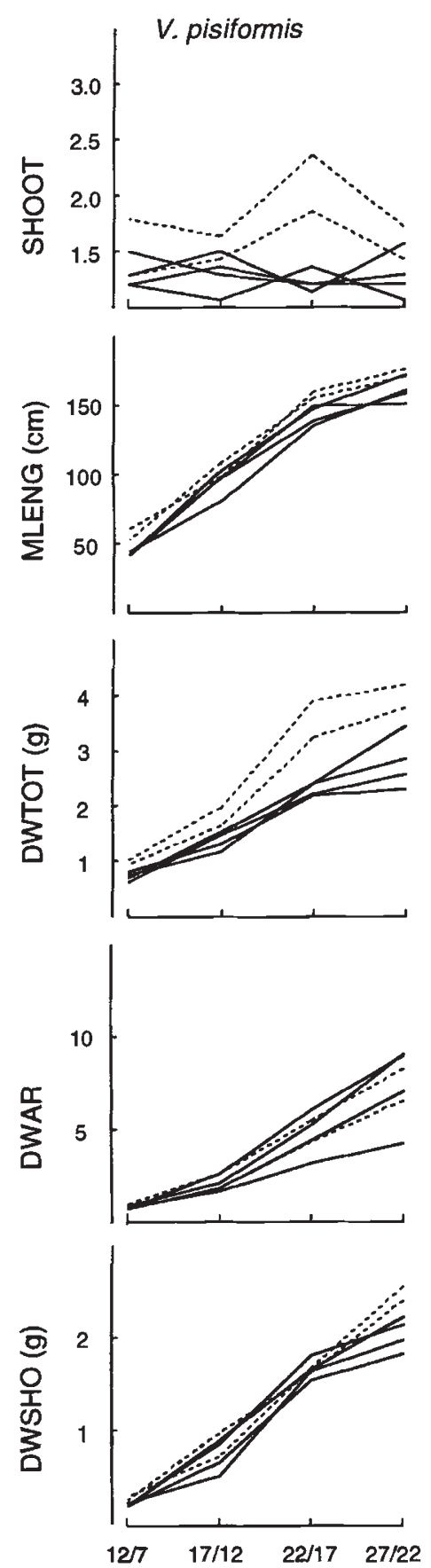
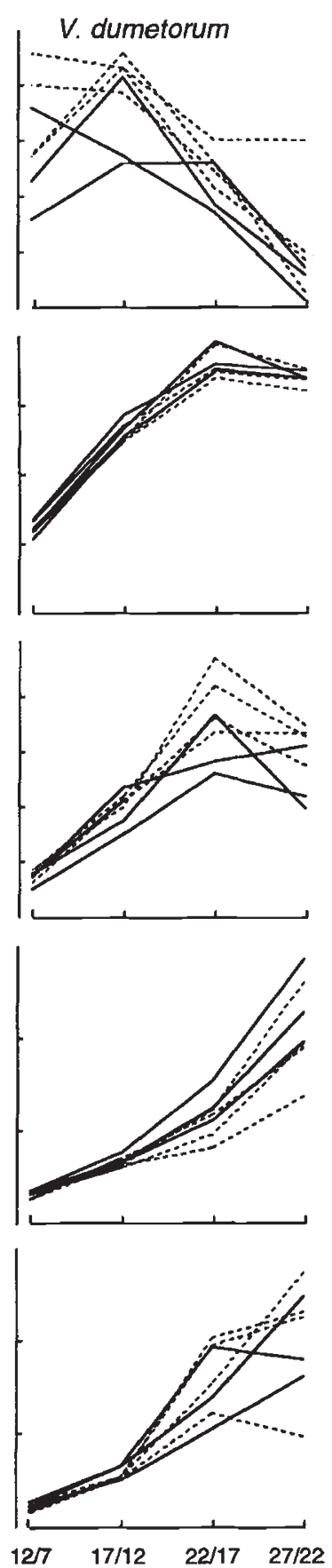
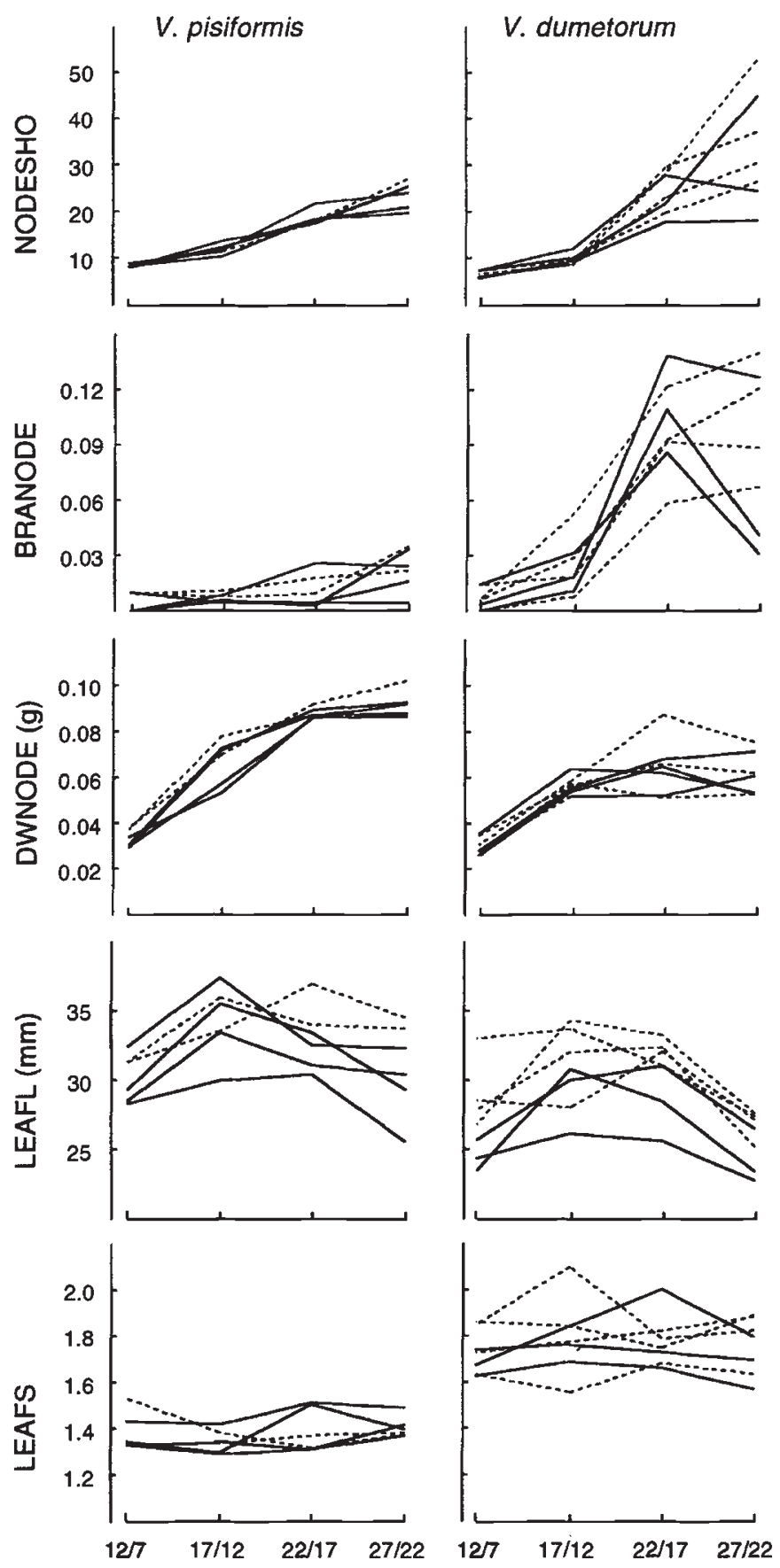

Fig. 1 Norms of reaction of growth traits in populations of Vicia pisiformis and V.dumetorum to four temperature treatments. Marginal populations are indicated by straight lines and central populations by dotted lines. 
DWTOT, DWNODE and BRANODE (Table 3; see also Table 6).

\section{Genetic variation in response}

Vicia pisiformis and $V$. dumetorum differed significantly in their response to temperature for most characters (Table 5). For instance, there was a tendency for some characters (e.g. SHOOT, MLENG and DWTOT) to reach a maximum value at lower temperatures in $V$. dumetorum than in $V$. pisiformis (Fig. 1).

Data from $V$. pisiformis revealed a significant population $\times$ treatment interaction for SHOOT,

Table 4 Species means $(X)$ and coefficients of variation (CV) across four temperatures (averaged over populations), and the correlation ( $r$ ) between population means in the two most extreme environments for 10 vegetative traits in Vicia pisiformis (pis) and V. dumetorum (dum)

\begin{tabular}{lcccccc}
\hline Character & $\begin{array}{c}\text { pis } \\
X\end{array}$ & $\begin{array}{c}\text { dum } \\
X\end{array}$ & $\begin{array}{c}\text { pis } \\
\mathrm{CV}\end{array}$ & $\begin{array}{c}\text { dum } \\
\mathrm{CV}\end{array}$ & $\begin{array}{c}\text { pis } \\
r\end{array}$ & $\begin{array}{c}\text { dum } \\
r\end{array}$ \\
\hline SHOOT & 1.42 & 2.26 & 0.130 & 0.307 & 0.599 & 0.578 \\
MLENG & 114.48 & 135.72 & 0.467 & 0.399 & 0.696 & 0.451 \\
DWAR & 3.77 & 5.34 & 0.786 & 0.747 & 0.338 & 0.714 \\
DWTOT & 2.06 & 2.29 & 0.551 & 0.550 & 0.734 & 0.402 \\
DWSHO & 1.27 & 1.09 & 0.684 & 0.803 & 0.831 & 0.375 \\
DWNODE & 0.070 & 0.053 & 0.398 & 0.314 & 0.449 & 0.113 \\
NODESHO & 15.64 & 18.37 & 0.456 & 0.683 & 0.414 & 0.297 \\
BRANODE & 0.011 & 0.054 & 0.767 & 0.903 & 0.148 & 0.168 \\
LEAFL & 32.14 & 28.47 & 0.071 & 0.105 & 0.802 & 0.524 \\
LEAFS & 1.38 & 1.76 & 0.033 & 0.034 & 0.150 & 0.742 \\
\hline
\end{tabular}

DWAR, DWTOT and LEAFS, whereas populations of $V$. dumetorum differed in response for all traits but MLENG, LEAFL and LEAFS (Table 3; see also Table 6). In $V$. pisiformis, central populations had a greater response to temperature (DWTOT) or a more distinct optimum temperature (SHOOT) than those in geographically marginal areas (Fig. 1). The average value for each population was positively correlated between the $12^{\circ} \mathrm{C} / 7^{\circ} \mathrm{C}$ and $27^{\circ} \mathrm{C} / 22^{\circ} \mathrm{C}$ regimes for all characters in both species (Table 4 ).

Maternal sibships in populations of $V$. dumetorum responded differently to temperature for DWTOT, DWSHO, NODESHO and LEAFL, whereas none of the traits was significantly affected by the family $\times$ environment interaction in $V$. pisiformis (Table 3 ). Hence, the variance arising from family $\times$ environment interaction was lower in $V$. pisiformis $(0-5$ per cent) than in $V$. dumetorum (0-18 per cent; Table 6).

\section{Discussion}

Average seed weight differed greatly between species and conspecific populations $(P<0.001$, unpublished data), but seedling size had little effect on traits expressed later in the ontogeny, when initial plant height was entered as a covariate (data not shown). This finding agrees with studies showing that the maternal influence disappears at later stages (e.g. Ouborg \& Van Treuren, 1995). In the following text, it is assumed that phenotypic differences between species, populations and families had a strong genetic component and that most characters are correlated with fitness. The latter assumption

Table 5 Results of nested, factorial analysis of variance of 10 vegetative traits in Vicia pisiformis and V. dumetorum

Source of variation

\begin{tabular}{lccccc} 
& \multicolumn{1}{c}{$\begin{array}{c}\text { Treatment } \\
\text { Character }\end{array}$} & $\begin{array}{c}\text { Species } \\
(3)\end{array}$ & $\begin{array}{c}\text { Population (species) } \\
(11)\end{array}$ & $\begin{array}{c}\text { Treatment } \times \text { species } \\
(3)\end{array}$ & $\begin{array}{c}\text { Treatment } \times \text { population } \\
(33)\end{array}$ \\
\hline SHOOT & $14.885^{* * *}$ & $29.025^{* * *}$ & $3.959^{* * *}$ & $15.322^{* * *}$ & $2.104^{* * *}$ \\
MLENG & $1036.975^{* * *}$ & $37.078^{* * *}$ & $4.481^{* * *}$ & $18.282^{* * *}$ & 0.846 \\
DWAR & $153.090^{* * *}$ & $9.352^{* *}$ & $3.272^{* *}$ & $4.423^{*}$ & $5.191^{* * *}$ \\
DWTOT & $118.899^{* * *}$ & 0.962 & $4.456^{* * *}$ & $6.147^{* *}$ & $2.360^{* * *}$ \\
DWSHO & $213.481^{* * *}$ & 4.530 & 1.909 & 0.910 & $1.969^{* *}$ \\
DWNODE & $157.349^{* * *}$ & $35.925^{* * *}$ & $2.943^{* *}$ & $12.304^{* * *}$ & 1.050 \\
NODESHO & $55.047^{* * *}$ & 2.998 & 1.469 & $4.690^{* *}$ & $6.212^{* * *}$ \\
BRANODE & $29.976^{* * *}$ & $31.745^{* * *}$ & $2.561^{* *}$ & $18.105^{* * *}$ & $3.419^{* * *}$ \\
LEAFL & $20.376^{* * *}$ & $9.003^{* *}$ & $6.610^{* * *}$ & 1.572 & $1.528^{*}$ \\
LEAFS & 0.793 & $80.145^{* * *}$ & $4.879^{* * *}$ & 0.625 & 1.047 \\
\hline
\end{tabular}

Values are $F$-ratios (degrees of freedom in brackets).

${ }^{*} P \leq 0.05 ;{ }^{*} P \leq 0.01 ;{ }^{* *} P \leq 0.001$.

(C) The Genetical Society of Great Britain, Heredity, 79, 268-276. 
Table 6 Relative variance components $( \pm \mathrm{SE})$ for 10 vegetative traits in Vicia pisiformis and $V$. dumetorum

\begin{tabular}{|c|c|c|c|c|c|}
\hline \multirow[b]{2}{*}{ Character } & \multicolumn{4}{|c|}{ Source of variation } & \multirow[b]{2}{*}{ Error } \\
\hline & Population & Family (population) & Treatment $\times$ population & Treatment $\times$ family & \\
\hline \multicolumn{6}{|l|}{ V. pisiformis } \\
\hline SHOOT & $12.8(7.0)$ & 0 & $5.0(1.4)$ & 0 & $82.1(6.4)$ \\
\hline MLENG & $6.1(4.7)$ & 0 & 0 & 0 & $93.9(4.7)$ \\
\hline DWAR & $18.8(13.4)$ & $0.3(1.9)$ & $21.6(4.6)$ & 0 & $59.3(9.2)$ \\
\hline DWTOT & $15.3(10.2)$ & $5.6(3.6)$ & $5.2(3.8)$ & 0 & $74.0(9.6)$ \\
\hline DWSHO & $0.4(1.5)$ & $0.4(3.2)$ & 0 & 0 & $99.3(3.1)$ \\
\hline DWNODE & 0 & $0.2(2.8)$ & 0 & 0 & $99.8(2.8)$ \\
\hline NODESHO & $0.3(2.1)$ & 0 & $3.0(3.8)$ & $5.4(7.2)$ & $91.3(7.4)$ \\
\hline BRANODE & $1.1(1.9)$ & 0 & 0 & $4.1(7.8)$ & $94.9(7.9)$ \\
\hline LEAFL & $11.8(7.9)$ & 0 & $1.2(2.8)$ & 0 & $86.9(8.0)$ \\
\hline LEAFS & $2.9(4.4)$ & $2.9(3.7)$ & $2.9(3.8)$ & 0 & $91.4(5.9)$ \\
\hline \multicolumn{6}{|l|}{ V. dumetorum } \\
\hline SHOOT & $6.4(6.3)$ & $11.6(4.6)$ & $7.5(4.3)$ & $5.4(6.0)$ & $69.2(7.6)$ \\
\hline MLENG & $2.8(2.9)$ & $3.1(3.6)$ & 0 & $1.9(7.1)$ & $92.2(7.2)$ \\
\hline DWAR & $10.8(9.5)$ & $6.1(3.8)$ & $19.2(7.3)$ & $4.3(5.7)$ & $59.6(8.7)$ \\
\hline DWTOT & $5.9(6.5)$ & $10.7(4.7)$ & $10.0(5.2)$ & $11.1(6.2)$ & $62.3(7.2)$ \\
\hline DWSHO & $14.2(4.3)$ & $0.4(2.5)$ & $14.2(5.8)$ & $11.4(4.7)$ & 59.7 (5.2) \\
\hline DWNODE & $13.2(12.9)$ & $6.6(5.4)$ & $13.2(8.6)$ & $0.7(8.6)$ & $66.2(13.5)$ \\
\hline NODESHO & $4.2(8.0)$ & $1.0(2.7)$ & 29.7 (9.6) & $13.6(5.7)$ & $51.4(7.4)$ \\
\hline BRANODE & $8.6(8.3)$ & $5.1(3.0)$ & $17.7(6.7)$ & 0 & $68.6(7.5)$ \\
\hline LEAFL & $13.8(8.4)$ & $1.5(3.7)$ & $3.4(3.7)$ & $18.0(6.9)$ & $63.4(8.1)$ \\
\hline LEAFS & $5.8(5.0)$ & $4.6(3.9)$ & 0 & $0.3(7.0)$ & $89.2(8.5)$ \\
\hline
\end{tabular}

seems reasonable for characters reflecting vegetative size and overall plant vigour, whereas the other traits have unknown relevance to fitness.

\section{Genetic variation vs, phenotypic plasticity}

The average effect of population and/or family was significant for a wide variety of traits, including vegetative size, leaf shape and the proportional allocation of biomass. About half of the traits were significantly variable at the between-population level in both species, whereas the between-family component reached significance for a greater number of characters in $V$. dumetorum (five) than in $V$. pisiformis (one). Populations and families also differed in their response to temperature, particularly in $V$. dumetorum. The presence of genetic variation at these levels shows that there is a potential for further evolutionary change in some characters. The significant level of genetic variation in $V$. pisiformis is particularly interesting in view of the low inter- and intrapopulation molecular variation in RAPD and RFLP (rDNA) markers found in a previous study (Gustafsson \& Gustafsson, 1994). Heritable variation in fitness components has also been docu- mented in other rare, threatened plants, including Plantago cordata (Meagher et al., 1978) and Senecio integrifolius (Andersson \& Widén, 1993; Widén \& Andersson, 1993), suggesting that rarity may not always be associated with low genetic variance for ecologically important traits.

Almost all the characters were significantly affected by temperature, the amount of the response ranging from 3 per cent to 90 per cent when standardized by the grand mean $(\mathrm{CV})$. The magnitude of response was similar in $V$ pisiformis and $V$. dumetorum, and there were no consistent differences in $\mathrm{CV}$ between categories of traits, except that leaf shape was phenotypically stable in both species.

If genetic variation and plasticity represent alternative adaptive strategies, there should be a negative association between these parameters (Marshall \& Jain, 1968). However, even though $V$. dumetorum exhibited significant genetic variation and genotype $\times$ environment interaction for a larger number of traits than $V$ p pisiformis, we found no tendency for $V$. dumetorum to be less plastic than its congener, and there was no trade-off between genetic and environmental variation on a trait-by-trait basis. Thus, our results provide no evidence of a negative 
relationship between phenotypic plasticity and genetic specialization, extending the results of other recent studies (Scheiner \& Goodnight, 1984; Schlichting \& Levin, 1984; Taylor \& Aarssen, 1988; MacDonald \& Chinnappa, 1989).

\section{Ecological breadth and reaction norm evolution}

Given that the average reaction norm can respond to selection, one would expect greater divergence in reaction norm parameters in the broadly adapted $V$. dumetorum than in the narrowly distributed $V$. pisiformis. This hypothesis is supported by our finding that populations of $V$. dumetorum were more divergent in their response to different temperatures than those of $V$. pisiformis. Furthermore, there appears to be a greater potential for reaction norm evolution in $V$. dumetorum, given the strong effect of family and family $\times$ treatment in this species. The tendency for $V$. dumetorum to maintain a higher shoot production across temperature regimes (broad ecological tolerance) and the presence of more divergent genotypes in $V$. dumetorum may have enabled this species to extend its ecological range beyond that of $V$. pisiformis.

We found no negative genetic correlations between fitness measured in different environments. Vegetative characters directly related to flower production were positively correlated between the most extreme temperature regimes, suggesting that there was little change in the ranking of populations over environments and that significant population $x$ environment interactions largely reflect differences among populations in the magnitude of response. These results provide little support for the hypothesis that increased adaptation to one habitat sacrifices adaptation to another habitat (Via \& Lande, 1985). Hence, genetically based trade-offs within the reaction norm may play a minor role in preventing $V$. dumetorum and $V$. pisiformis from exploiting a wider range of habitats (cf. Andersson \& Widén, 1993).

\section{Marginal vs. central populations}

Inbreeding, genetic drift and restricted gene flow result in genetic erosion, particularly in geographically marginal populations (Soulé, 1973). Assuming that phenotypic plasticity (or broad ecological tolerance) represents an alternative to genetic variation as a mode of adaptation, one would expect genotypes from marginal populations to be more plastic and/or more broadly adapted than genotypes from central populations (Stewart \& Nilsen, 1995). Data from $V$. pisiformis and $V$. dumetorum are not consist- ent with this hypothesis: marginal populations did not exhibit greater phenotypic plasticity than central populations, and central populations generally had a greater overall performance than those from marginal sites, at least in $V$. pisiformis. As for the latter result, it is important to stress that the experimental conditions may have been more favourable to plants representing the central (southern) distribution, making it difficult to separate the effect of latitude and marginality on reaction norm parameters. Moreover, selection in marginal conditions may have reduced phenotypic plasticity to produce more specialized, better adapted populations, even though wide plasticity may have been important in the initial establishment of these populations.

\section{Concluding remarks}

The present study quantified genetic variation for mean performance and plasticity in marginal and central populations of two rare species. We tested the hypotheses that heritable variation and phenotypic plasticity represent alternative strategies, that the specialized $V$. pisiformis is less variable than the more broadly adapted $V$. dumetorum and that marginal (northern) populations are more plastic (or tolerant) than central populations. There was no trade-off between genetic variation and phenotypic plasticity, but our results indicate a tendency for $V$. dumetorum to perform better and to show higher levels of genetic variation than $V$. pisiformis, and a trend towards higher overall performance in central populations of $V$. pisiformis. Given the genetic variation in $V$. pisiformis (this study) and the apparent lack of molecular variation in this species (Gustafsson \& Gustafsson, 1994), it remains to be seen whether such a discrepancy also occurs in $V$. dumetorum. Comparison of polygenic and molecular variation will be the subject of further studies.

\section{Acknowledgements}

We are indebted to Professor Gösta Eriksson, who made this study possible, Johan Samuelsson and Barbro Black for excellent and enjoyable assistance during German and Swedish seed collections, Vera Hadincova for kindly providing Czech seeds, and Xinrong Gao for skilfully helping with the harvest.

\section{References}

ANDERSSON, S. AND WIDÉN, B. S. 1993. Reaction norm variation in a rare plant Senecio integrifolius (Asteraceae) Heredity, 73, 598-607. 
ARONSSON, M., HALLINGBÄCK, T. AND MATTSON, J-E. 1995. Rödlistade växter $i$ Sverige 1995 (Swedish Red Data Book of Plants 1995). Artdatabanken, Uppsala.

BLACK, S., ERIKSSON, G., GUSTAFSSON, L. AND LUNDKVIST, K. 1995. Ecological genetics of the rare species Vicia pisiformis: Quantitative genetic variation and temperature response in biomass and fecundity. Acta Oecologica, 16, 261-275.

BRADSHAW, A. D. 1965. Evolutionary significance of phenotypic plasticity in plants. Adv. Genet., 13, 115-155.

Bulmer, M. G. 1980. The Mathematical Theory of Quantitative Genetics. Clarendon Press, Oxford.

COOK, S. A. AND JOHNSON, M. P. 1968. Adaptation to heterogeneous environments. I. Variation in heterophylly in Ranunculus flammula L. Evolution, 22, 496-516.

ELLENBERG, H., WEBER, H. E., DÜLl, R., WIRTH, V., WERNER, W. ANd PAulissen, D. 1991. Zeigerwerte von Pflanzen in Mitteleuropa. Erich Goltze KG, Göttingen.

gustafsson, L. 1991. Ärtvicker, Vicia pisiformis i Sverige (Vicia pisiformis in Sweden). Sv. Bot. Tids., 85, 21-32. (In Swedish with English abstract.)

gUSTAFSSON, L. 1992. Buskvicker, Vicia dumetorum i Sverige (Vicia dumetonum in Sweden). Sv. Bot. Tids., 86, 233-242. (In Swedish with English abstract.)

GUSTAFSSON, L. AND GUSTAFSSON, P. 1994. Low genetic variation in Swedish populations of the rare species Vicia pisiformis (Fabaceae) revealed with RFLP (rDNA) and PCR (random priming). Pl. Syst. Evol., 189, 133-148.

HANELT, P. AND METTIN, D. 1989. Biosystematics of the genus Vicia L. (Leguminosae). Ann. Rev. Ecol. Syst., 20, 199-223.

KRUCKEBERG, A. R. AND RABINOWITZ, D. 1985. Biological aspects of endemism in higher plants. Ann. Rev. Ecol. Syst., 16, 447-479.

LOVELESS, M. D. AND HAMRICK, J. L. 1984. Ecological determinants of genetic structure in plant populations. Ann. Rev. Ecol. Syst., 15, 65-95.

MACDONAld, S. E. AND CHINNAPPA, c. C. 1989. Population differentiation for phenotypic plasticity in the Stellaria longipes complex. Am. J. Bot., 76, 1627-1637.

MARShall, D. R. AND JAIN, s. K. 1968. Phenotypic plasticity of Avena fatua and A. barbata. Am. Nat., 102, 457-467.
MEAGHER, T. R., ANTONOVICS, J. AND PRIMACK, R. 1978. Experimental ecological genetics in Plantago. III. Genetic variation in relation to survival of Plantago cordata, a rare species. Biol. Conserv., 14, 243-257.

OUBORG, N. J. AND VAN TREUREN, R. 1995. Variation in fitness-related characters among small and large populations of Salvia pratensis. J. Ecol., 83, 369-380.

Rabinowitz, D. 1981. Seven forms of rarity. In: Synge, H. (ed.) The Biological Aspects of Rare Plants, pp. 205-217. John Wiley \& Sons, Chichester.

SAS INSTITUTE INC. 1989. SAS/STAT Users Guide, Version 6, 4th edn, Vol. 2. SAS Institute, Cary, NC.

SCHEINER, S. M. AND GOODNIGHT, C. J. 1984. The comparison of phenotypic plasticity and genetic variation in populations of the grass Danthonia spicata. Evolution, 38, $845-855$.

SChlichting, C. D. AND Levin, D. A. 1984. Phenotypic plasticity of annual Phlox: tests of some hypotheses. Am. J. Bot., 71, 252-260.

SILANDER, J. A. 1985. The genetic basis of the ecological amplitude of Spartina patens. II. Variance and correlation analysis. Evolution, 39, 1034-1052.

SOULÉ, M. 1973. The epistasis cycle: a theory of marginal populations. Ann. Rev. Ecol. Syst., 4, 165-187.

STEWARt, C. N. And Nilsen, E. T. 1995. Phenotypic plasticity and genetic variation of Vaccinium macrocarpon, the American cranberry. I. Reaction norms of clones from central and marginal populations in a common garden. Int. J. Plant Sci., 156, 687-697.

SULTAN, S. E. 1987. Evolutionary implications of phenotypic plasticity in plants. Evol. Biol., 21, 127-178.

TAYLOR, D. R. AND AARSSEN, L. W. 1988. An interpretation of phenotypic plasticity in Agropyron repens (Graminae). Am. J. Bot., 75, 401-413.

VIA, s. 1987. Genetic constraints on the evolution of phenotypic plasticity. In: Loeschcke, V. (ed.) Genetic Constraints on Adaptive Evolution, pp. 47-71. SpringerVerlag, Berlin.

VIA, S. AND LANDE, R. 1985. Genotype-environment interaction and the evolution of phenotypic plasticity. Evolution, 39, 505-523.

WIDÉN, B. AND ANDERSSON, s. 1993. Quantitative genetics of life-history and morphology in a rare plant, Senecio integrifolius. Heredity, 70, 503-514. 